\title{
Manufacture of Gambir Leaf Press Impac System in Efforts to Increase Productivity of Gambir Farmers
}

Nelvi Erizon, Jasman, Syahrul and Wakhinuddin

Jurusan Teknik Mesin, Fakultas Teknik, Universitas Negeri Padang, Indonesia

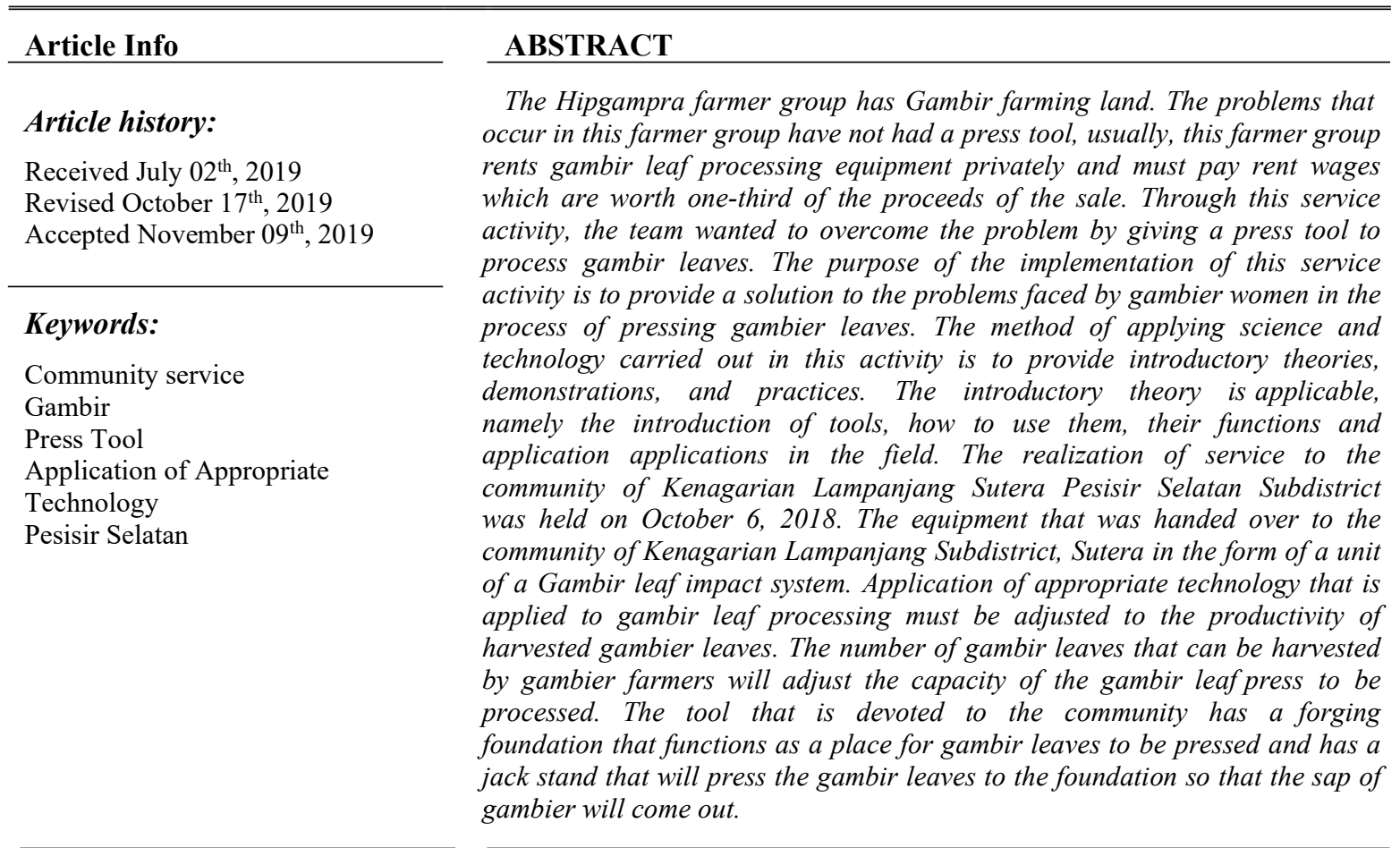

Corresponding Author:

Nelvi Erizon,

Jurusan Teknik Mesin, Fakultas Teknik, Universitas Negeri Padang

Jln. Prof. Dr Hamka Air Tawar, Padang (25131), Sumatera Barat, Indonesia

Email: nelvi@ft.unp.ac.id

\section{INTRODUCTION}

Gambir is a traditional Indonesian commodity that has been cultivated since before World War I, especially outside Java such as West Sumatra, Riau, South Sumatra, Aceh, West Kalimantan and Maluku. Gambir in Indonesia is widely cultivated in West Sumatra (West Sumatra). In fact, $90 \%$ of the world's gambier markets are produced from this province. At present, in West Sumatra, there are at least 450,000 hectares of land potential for expansion of gambier plantations, especially in the mountains with sloping land conditions.

Gambir plants are known by the Latin name Uncaria gambir Roxb, the name English; Cat's Claw, Spanish name; Uña de Gato or Indian name; Vilcacora. Regional names for gambir in Indonesia, namely gambir. [1] Gambier plants (Uncaria gambir Roxb) commonly grow wild in the woods and other places that land slightly tilted and get enough sunlight and even rainfall every year. It usually grows between $200 \mathrm{~m}$ $900 \mathrm{~m}$ above sea level. These plants are mostly located in Kalimantan and Sumatera. This plant is a shrub which has a hard stem that twists. The leaves are short-stemmed and light green. The flowers are white, small 
and round cob. The gambir part harvested is leaves and twigs which are then processed to produce economically valuable gambir extracts [2]. In West Sumatra, gambier plants grow well in the Limapuluh Kota, Pesisir Selatan, and another level II regions. In Limapuluh Kota Regency there are 11,937 hectares of gambir with a production of 7,379 tons per year, in Pesisir Selatan Regency as many as 2469 hectares with a production of 688 tons per year, and other Districts with an area of 175 hectares but most have not produced optimally. Surantih is the largest gambir producing sub-district in the South Pesisir Regency, which is an area of 5,698 ha with a total production of 4,986 tons per year or $34 \%$ of the total production of Pesisir Selatan Regency. Pesisir Selatan regency is widely spread gambier, the spread of gambier plants starting from Siguntur, Koto XI Tarusan Subdistrict to Surantih Region. The processing system is carried out both traditionally and conventionally. This condition causes production to be less optimal. Gambir processing equipment is an important thing in the business of producing sap gambier. The processing of gambir is the process of removing sap contained in leaves and twigs by using presses, while the material to be released is catechin, this content determines the gambir quality requirements. The gambir part harvested is leaves and twigs which are then processed to produce economically valuable gambir extracts. [2] Harvesting and pruning of leaves are done after the plant is 1.50 years old. Pruning is done 2-3 times a year at intervals of 4-6 months. Pangkasan leaves and twigs must be processed immediately because if the processing is delayed more than 24 hours, the sap will decrease [2] In general, there are several stages of processing that must be passed, after bringing the material that has been harvested to the site of the press and weighing the material. The stages of gambir processing consist of:

\subsection{Boiling Materials}

The leaves and twigs that have been picked are put in a container in the form of a bamboo basket (kapuak = Minangkabau) with the knitting (jala) inside the capuak first. The raw material in the container must be compacted in such a way. Traditionally, the farmers do this work by hanging on the crossbar of the felt house and stomping their feet against the raw material in the container with full force. In the boiling process, the most important thing is the process of releasing catechins from leaf cells. Apart from this catechin, it will determine the amount of gambier produced. The process of releasing catechin grains is very dependent on the proper boiling process. Boiling is traditionally carried out for approximately 1.5 hours for each capuak. During boiling the capuak is carried out once so that boiling is evenly distributed to all ingredients. In addition, bundles of gambir are sometimes stabbed with sharp wood to give the hot waterway into the gambir bundle.

\subsection{Pressing Materials}

The ingredients that have been boiled are then pressed using a press tool. Traditionally, the material to be pressed first must be wrapped in a rope to facilitate the pressing process and keep the material being pressed away. This winding process takes around 30-45 minutes. The press tool that has been used by farmers is not possible to be done repeatedly for one unit of material because the time used for one press is long enough so that the heat contained in the material after boiling will decrease. Furthermore, these windings will also cause the optimal compression that is done because it is held back by the twisting rope. This situation causes the process of sap release to be not optimal because the temperature of the material has been reduced, where [3] explained that the temperature needed by sap gambir to escape from leaf tissue and twigs optimally should not be less than $900 \mathrm{C}$. In press gambir, there are several factors that must be considered, namely yield, the maximum pressure in gambir bundles, dry gambier catechin levels, ash content, moisture content after drying. The results of pressing gambir leaves from traditional boiling, still leaving about $25 \%$ of the leaf sheet that has been pressed still has a thick green colour and thick leaves this indicates that the still green part still contains catechins. This means that there are still more or less $25 \%$ of the raw material of gambir leaves that are still not extracted. At present, there are several types of felt presses used by farmers in West Sumatra that can affect the yield and quality of dried gambier produced due to the maximum pressure difference in pressed material.

But when viewed from the durability of the tool, it will be found that traditional tools that use wooden frames will be easily broken due to the pressure given is often not in accordance with the strength of the tool frame. Likewise with screw thread press systems that require considerable energy to operate, even though they show good results, but it will be difficult to bring to gambir gardens which are generally in areas with hilly topography. The processing of factory models is less attractive to farmers because in general, they do not want to sell their leaves to be processed elsewhere because the processed pulp is always distributed in their planting area as fertilizer. Duration of presses ranges from 10-15 minutes depending on the type of tool used. Leaf sap and juice from the leaf sap (extract) from the press are collected with a plastic basin for further deposition. [4] 


\subsection{Deposition of sap}

Gambir extract from kempaan is transferred into a long nail made of wood by first filtering so that leaf impurities carried in the liquid can be separated, then the deposition process is carried out. Sedimentation of the sap can be stimulated by rubbing the sap with a collection of gunny/plastic sack fibres. Inside my parake, it is usually separate between the crystals found at the bottom which are predominantly composed of catechins, while the brownish liquid at the top is tannin or catechu tenant. As far as possible after catechu that water is taken, the new kitchen crystals are collected and then drained. This deposition process usually takes around 20 hours. [5]

\subsection{Imitation of Gum}

Imitation is done by inserting the deposits of sap (crystallized sap) into a gunny sack and squeezed with a heavy object. Draining water is stored in my paw, where this water can usually be reused for boiling. This imitation is carried out for 10-20 hours, depending on the amount of material drained. After obtaining chunks of gambir sap which are in the form of a solid paste, then printing can be done subsequently.

\subsection{Printing}

Gambir extract that has passed through the slicing process will be shaped like a paste. This pasta can be printed. Printing is done using a mould made of bamboo (cupak = Minangkabau), which has a diameter of about 1 inch. In West Sumatera there are 3 types of moulds, consisting of cylindrical shapes, coins, and concave cylinders.

For consumption purposes, gambier is printed using concave cylindrical moulds, and for industrial/export purposes gambier is printed with a coin or cylindrical mould. For 1 person who prints I $\mathrm{kg}$ gambir it takes 20-25 minutes.

\subsection{Drying}

Gambir that has been printed is placed in a container made of bamboo/wood that looks like a tray, neatly arranged and ready to be dried in the sun or on a heating stove/gambir leaf boilers. This drying is carried out for 3-4 days or depending on the weather if it is dried in the sun. [6]

Every processing process uses the equipment, the equipment used includes traditional and conventional equipment. The traditional equipment in question is that the work process is done manually, for example for gambir leaf felts, only done with a wooden punch. Conventional equipment working processes are carried out using technologies such as hydraulic jacks, screw presses. The production of gambir latex produced depends on the quality of the equipment used. The equipment used will certainly experience depreciation, this depreciation will be followed by production yields. If low production yields simultaneously will also be followed by low production results.

In processing gambier leaves, farmers still rent gambir leaf processing equipment. This is because not all farmers are able to build gambir leaf processing equipment. The number of funds needed to build a unit of gambir leaf processing equipment + Rp. 20,000,000 (twenty million rupiahs). Some farmers prefer to rent gambir leaf processing equipment. This rental system is paid based on profit sharing. The rental price is onethird of the proceeds obtained after the sap of gambier is ready for sale.

This problem is the concern of the service team. The welfare of farmers will be difficult to achieve if their crops cannot be fully obtained. Through the implementation of this service, the dedication team wanted to help gambir farmers in kenagarian Lampanjang Rawang in the form of making a unit of impact system press which can be used by farmers in handling one of the processes of gambier.

The purpose of the implementation of this service activity is to provide a solution to the problems faced by gambier women in the process of pressing gambier leaves. The length of time needed and the amount of energy that runs out during the process of pressing the gambir leaves becomes the focus of the dedicated team in creating innovations in gambir system impact leaf press. The benefits obtained in this service activity are the implementation of the obligation of the tri dharma of the high level of the dedication and assisted TEAM of gambier farmers in the process of pressing gambier leaves. 


\section{METHOD}

The application of science and technology is done by giving demonstrations and direct applications in the field about how to do the pressing process with the press system and impact so that the production process of gambier sap can be increased and optimal. The press and impact system is carried out with several stages including:

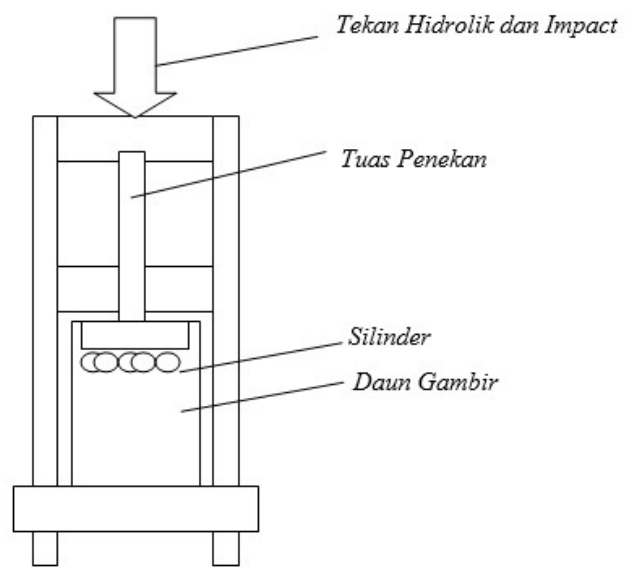

Figure 1. Gambir Leaf Press

2.1 After the process of withering gambir leaves then gambir leaves are placed on slender until it is near full. The position of the cylinder is placed in a position in the press. This cylinder position is in the middle of the pressure shaft.

2.2 The pressure shaft can be driven by two methods, namely with a hydraulic jack or with a rectangular screw. The pressure shaft is lowered gradually until the leaves are runny in the cylindrical experience pressing.

2.3 At the time the gambir gum content starts to come out, the pressure suppressor shaft is shocked or impacted. With this surprise, the sap of gambier will spurt out from the holes in the cylinder.

2.4 The pressing process is carried out repeatedly, namely pressing, impact, and so on until the gambir sap optimally exits the leaf.

The method of applying science and technology carried out in this activity is to provide introductory theories, demonstrations, and practices. The introductory theory is applicable, namely the introduction of tools, how to use them, their functions and application applications in the field.

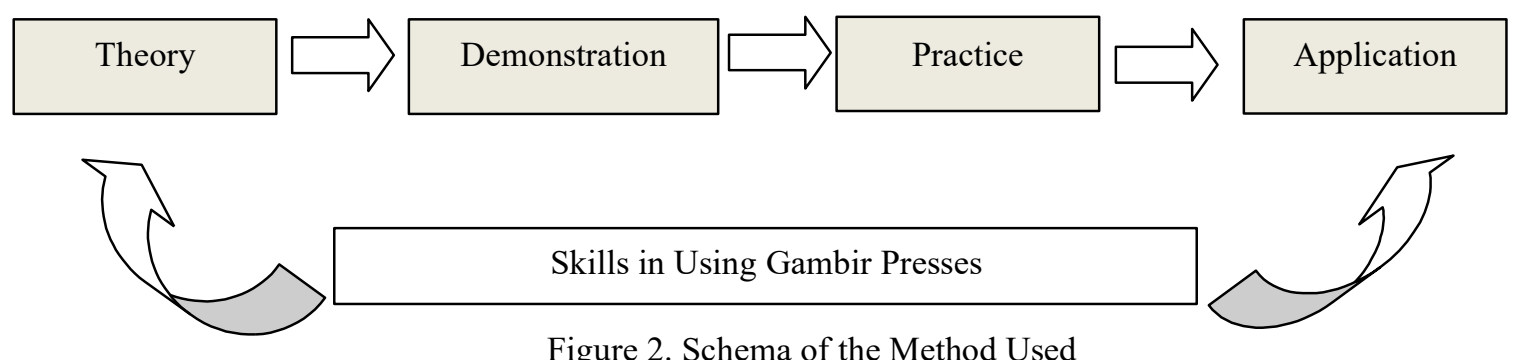

Figure 2. Schema of the Method Used

This method is adjusted to the schematic problem-solving framework. Problems arise because of various types of factors, the target audience is gambier farmers. In accordance with the objectives to be achieved in this activity is to produce farmers who are skilled and responsive to appropriate technology while having the motivation to entrepreneurship, the method applied is by providing direct training to farmers to carry out various types of operating techniques for gambir leaf press systems impact.

The demonstration method in question is a method that provides a direct demonstration of how to use hydraulic press systems that are correct in accordance with the specified techniques and procedures. Participants can immediately see, imitate and try the techniques and procedures using a hydraulic press system press machine in accordance with the established standard of operation. The method used in 
community service activities in the Kanagarian Lampanjang Rawang Pesisir Selatan farmer group is carried out by the following steps:

\subsection{Field Survey}

Field surveys were conducted to analyze the processing characteristics of gambir leaves to be processed. The characteristics of gambir leaves in question are thickness, shape and dimensions of leaves to be pressed, flexibility or elasticity of leaves to be processed. The survey was also carried out by looking directly at the process of pressing the gambir leaves carried out by gambier farmers.

Application of appropriate technology that is applied to gambir leaf processing must be adjusted to the productivity of harvested gambier leaves. The number of gambir leaves that can be harvested by gambier farmers will adjust the capacity of the gambir leaf press to be processed.

\subsection{Making the hydraulic press system design and impact of gambir leaves}

This design activity was carried out in the fabrication workshop of the FT-UNP Mechanical Engineering

Department. In the design process this is done in several stages, namely:

1. Identify characteristics of gambir leaves.

2. Analyzing component components used

3. Determine the principle of working the machine

4. Determine the force used as a driver

5. Select materials that are suitable for machine construction

6. Make design drawings and detailed drawings of all engine components

7. Cutting material, forming, connecting and working on all engine components in accordance with working drawings. The process starts with making the engine frame, body, driving position, the transmission system used, and so on,

8. Assembling engine components

9. Conduct several trials.

\subsection{Audience Target}

The target audience at this community service activity is gambier farmers who are in Kenagarian Lampanjang Sutera Pesisir Selatan District.

Table 1. Program Activities that will be carried out on the Target audience

\begin{tabular}{|c|c|c|c|}
\hline No & Activities & Time & Information \\
\hline 1 & $\begin{array}{l}\text { Survey Location Activities to find out the characteristics } \\
\text { of gambir leaves }\end{array}$ & 1 day & Team \\
\hline 2 & Discuss with devices of Nagari and target audiences & 1 day & Team and Device Nagari \\
\hline 3 & $\begin{array}{l}\text { Creating a system design Hydraulic press and impact } \\
\text { gambir leaves }\end{array}$ & 3 week & Team and students \\
\hline 4 & Operational testing of gambir leaf press & 1 week & Team and students \\
\hline 5 & $\begin{array}{l}\text { Check the process and results of pressing the leaves of } \\
\text { gambir }\end{array}$ & 2 week & Team and balai POM \\
\hline 6 & $\begin{array}{l}\text { Adjust the capacity, volume, diameter and height of the } \\
\text { cylinder, hydraulic press steps and the pressure needed } \\
\text { for pressing the leaves of gambir }\end{array}$ & 1 week & Team and Target Audiences \\
\hline 7 & Demonstration of activities with the target audience & 1 day & Team and Target Audiences \\
\hline 8 & $\begin{array}{l}\text { Application of appropriate technology for hydraulic } \\
\text { press and impact systems }\end{array}$ & 1 day & Team and Target Audiences \\
\hline 9 & $\begin{array}{l}\text { Information dissemination for the community at the } \\
\text { location of community service activities }\end{array}$ & 1 day & Team and Target Audiences \\
\hline
\end{tabular}




\section{RESULTS AND DISCUSSION \\ 3.1 Making Proces}

Gambir leaf press tool made in the Fabrication workshop of the UNP FT Engineering Department. In the process of making a TEAM service tool involving two students. Benefits for students participating in this activity can be the final task which is one of the requirements to complete the student Diploma education. The stages of this manufacturing process are:

\subsubsection{Design of gambir leaf maker}

The design process is done by using the 2008 version of the Autocad application. Job drawing is done by students. The design of this tool is made by using a jack as a pressure force. The design of the material to be used is to use a $\mathrm{U} 100$ profile iron.

\subsubsection{Frame Making Process.}

The main frame on the gambir leaf press machine, made with U 100 iron which is installed double on each main frame of the frame. This arrangement aims to make the framework of this tool strong. Here is a picture of the frame making process.

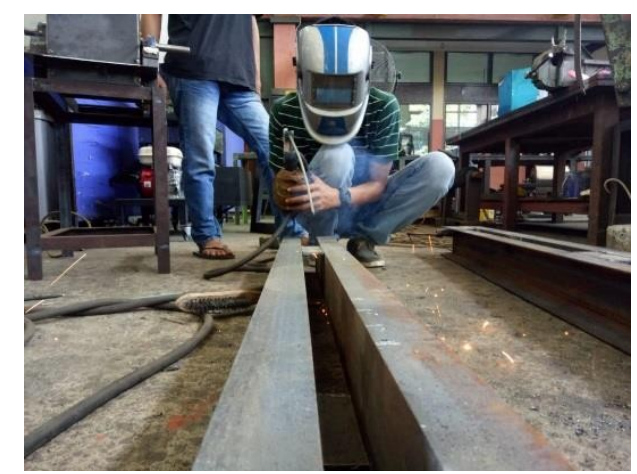

Fig. 2. Frame Making Process

\subsubsection{Making a Compound Landauer}

The forging platform is made of $250 \mathrm{H}$ beam iron. The choice of the use of the $\mathrm{H}$ beam 250 iron is because the pressing foundation will receive the greatest load. This platform functions as a place for gambir leaves to be pressed.

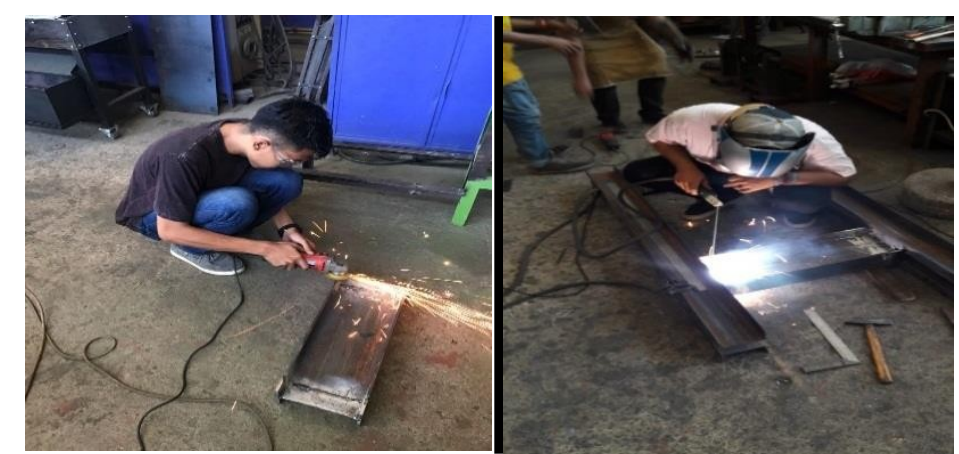

Fig. 3. The Making Process of the Forging Platform

\subsubsection{Making the Stand Position}

The jack stand on this press is made with $20 \mathrm{~mm}$ thick strip iron. this holder will press gambir leaves to the foundation so that the sap of gambier will come out. 


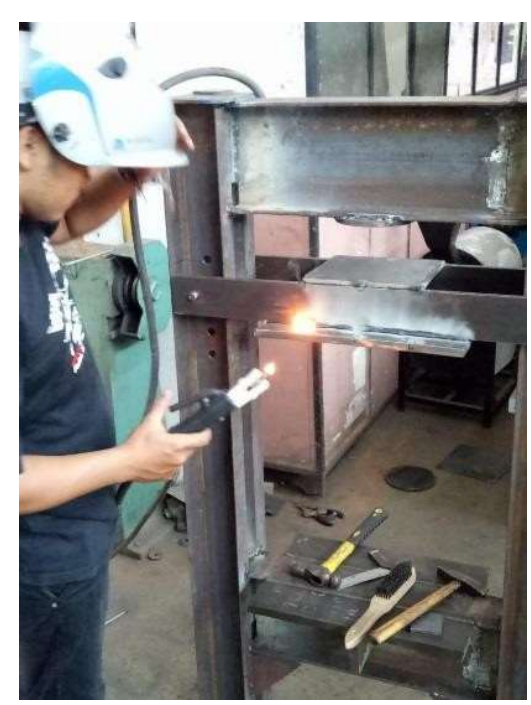

Fig. 4. The Process of Making a Push Stand

\subsubsection{Finishing Process}

The finishing process is the grinding process in parts that are still rough. The process of finishing on this press includes the painting process.

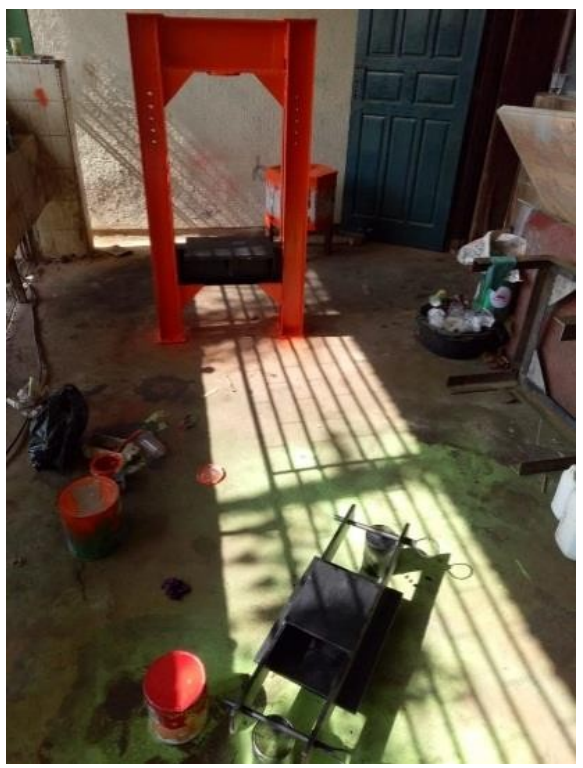

Fig. 5. Finishing Process

\subsection{Implementation Results}

As the realization of community service, the delivery and counselling of the operation of the equipment have been implemented which is applied to the target audience in the Kenagarian Lampanjang Sutera Pesisir Selatan District. The realization of service to the community of Kenagarian Lampanjang Sutera Pesisir Selatan Subdistrict was held on October 6, 2018. The equipment that was handed over to the community of Kenagarian Lampanjang Subdistrict, Sutera in the form of a unit of a gambir leaf impact system. This place of handover to the community is held at the Office of the Mayor of Nagari Kenagarian Lampanjang, Sutera Pesisir Selatan District.

Journal homepage: http://teknomekanik.ppj.unp.ac.id

DOI: https://doi.org/10.24036/tm.v2i2.2372 


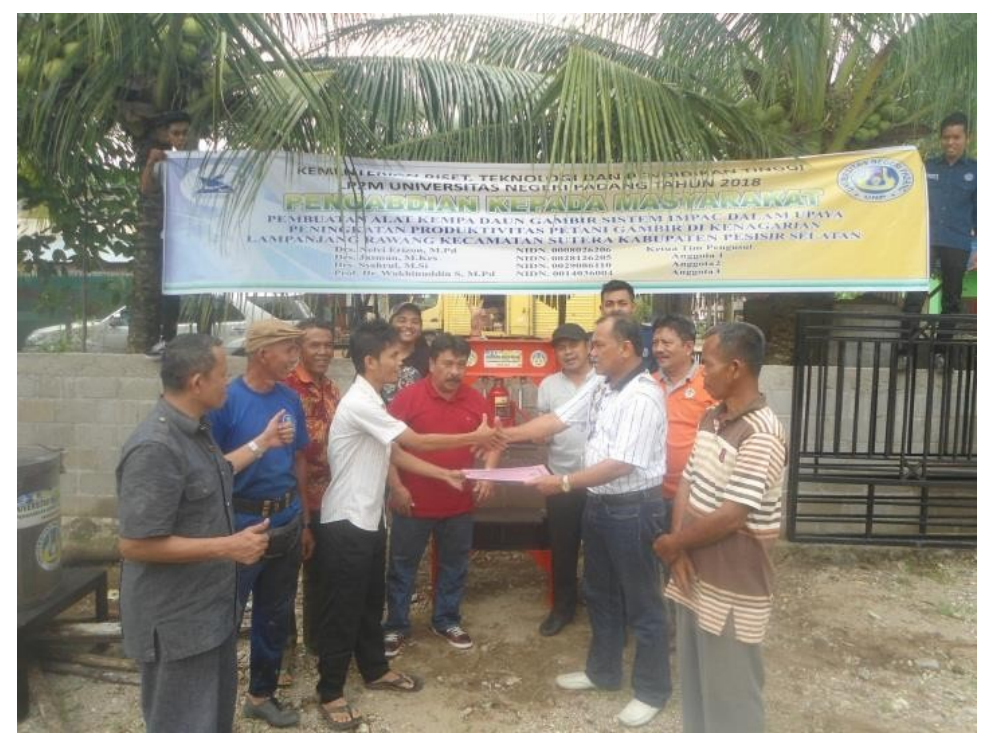

Fig. 6. Handover of community service

In addition to handover of the tools, demonstrations were also carried out on the operation of the equipment in front of the community, especially the gambier farmers. The demonstration in question is to provide a direct demonstration of how to use the gambir leaf press tool that is the correct impact system according to the specified techniques and procedures. The community can immediately see, imitate and try the techniques and procedures using the impact system gambir leaf press in accordance with the established standard of operation. Application of appropriate technology that is applied to gambir leaf processing must be adjusted to the productivity of harvested gambier leaves. The number of gambir leaves that can be harvested by gambier farmers will adjust the capacity of the gambir leaf press to be processed. The tool that is devoted to the community has a forging foundation that functions as a place for gambir leaves to be pressed and has a jack stand which will press the gambir leaves to the base so that the sap of gambier will come out.

\section{CONCLUSION}

The main frame of the press is made using a $U 100$ profile iron which is installed double. This is done to make the frame strong and durable. The pressing process on this press uses a 30-ton jack. This gambir leaf press is assumed to make the pressing process faster and more efficient.

\section{REFERENCES}

[1] Pambayun, R., M. Gardjito, S. Sudarmadji dan K. R. Kuswanto., Kandungan Fenol Dan Sifat Antibakteri Dari Berbagai Jenis Ekstrak Produk Gambir (Uncaria gambir Roxb.), Majalah Farmasi Indonesia, 18 (3): 2007

[2] Kasim et al., Pengolahan Hasil dan Kelayakan Usahatani Gambir (Uncaria gambir Roxb.) di Kabupaten Lima Puluh Kota. Buletin TRO, 2005: 15 (1)

[3] Suherdi. Kehidupan Sosial Ekonomi Petani Gambir di Kabupaten pakpak Bharat. Tesis. Medan: Sekolah Pasca Sarjana, Universitas Sumatera Utara; 2012

[4] Syamsu, dkk. Gumbira-Said. Bogor: Jurusan Teknologi Industri Pertanian, FTP, IPB. 2009

[5] Nazir, Peningkatan nilai tambah Gambir melalui diversifikasi produk, Badan Pelaksana Penyuluhan Pertanian, Perikanan dan Ketahanan Pangan Kabupaten 50 Kota, 2000

[6] Hiller K dan Melzig M.F., Die große Enzyklopaedie der Arzneipflanzen und. Drogen, Elsevier Spektrum Verlag, Heidelberg, (bagian kandungan bahan), Ho, C.H.L., Cacacea, J.E., 2007 